\title{
Upholding Cianjur Culture Wisdom as an Effort to Strengthen Sundanese Language and Culture in Nurturing the Nation's Character
}

\author{
Iis Ristiani \\ Department of Indonesian Education, Universitas Suryakancana, Cianjur, Indonesia \\ Email address: \\ iisristiani@unsur.ac.id \\ To cite this article: \\ Iis Ristiani. Upholding Cianjur Culture Wisdom as an Effort to Strengthen Sundanese Language and Culture in Nurturing the Nation's \\ Character. International Journal of Language and Linguistics. Vol. 7, No. 6, 2019, pp. 298-301. doi: 10.11648/j.ij11.20190706.17
}

Received: September 5, 2019; Accepted: September 24, 2019; Published: November 7, 2019

\begin{abstract}
The Cianjur community has a cultural movement by introducing its seven cultural pillars. The seven pillars of culture are ngaos (recite), mamaos (singing art), maenpo (martial arts), tatanen (farming), tangginas (agile), someah (polite) and sauyunan (mutual cooperation). The seven pillars of culture are the local wisdom of the Cianjur people who uphold the language and culture that exists, namely Sundanese language and culture. The embedded and growing power to preserve local wisdom is also part of the effort to maintain the nation's character. The purpose of this article is to analyze the cultural wisdom of Cianjur Regency as an effort to strengthen Sundanese language and culture in maintaining national character. The conclusion in this article is in human life, so that communication runs well, humans choose and use language according to their function. That is why communication is expected to run effectively. Language, as a communication tool used by humans to optimize their role as social creatures. Language is cultured. Both have a very close relationship. As a medium to express ideas, ideas, opinions, thoughts or feelings, the language used by someone reflects the thoughts and culture of that person. Thus, language, culture, and character have a very big role for humans in carrying out their functions as social beings. For the people of Cianjur, preservation of language and culture is bound in the seven pillars of Cianjur culture.
\end{abstract}

Keywords: Cultural Pillars, Local Wisdom, the Role of Language, Sundanese Culture, National Character

\section{Introduction}

"Where the earth is based, there the sky is held up". That is what the Malay proverb says [1]. That is, wherever we are, we need to understand the context. Likewise with the context of the Cianjur community as part of the Sundanese community. As part of this context is the use of language according to the context or contextual. We all realize, that in human life as social beings, language has a very big role. Language is a form of culture. Often we hear the saying "be careful what you think, because the mind will bear fruit, and also be careful what is said, because words have an urge to act. If the act is repeated, it will become a habit" [2]. Habits on someone shows or reflects the character of that person.

Through existing language, we can recognize the culture reflected in it. Therefore, the assessment of culture in the language used needs to be stated in advance about the aspects of meaning contained therein [3]. In addition, in this description also explained matters relating to the role of Sundanese language and culture in Sundanese people's lives; and Sundanese language and culture in maintaining national character.

Important descriptions in this discussion are language, culture, and character as well as the development of the seven cultural pillars of the Cianjur community. When someone speaks, it shows the culture and character of that person. In it implies the mind and describe the ideas, ideas, or feelings of the speaker. In relation to this, Durk Gorter [4] says that the outlook on life and culture of a society is determined by the language of the community itself. Therefore, the language set by a society will be a sign or feature or symbol of the worldview and cultural identity of the community.

When someone speaks by speaking out a number of words from his mouth, what we hear is the outer form of the person's language, and the inner form is his mind. It is not 
wrong to say that language is a symbol of personal or national identity. It is true as said by Henry Guntur Tarigan [5] which mentions the unique features of certain languages can be related to the unique characteristics of the people who use them according to the place where the language is used.

So strong is language and culture in influencing individuals or nations, it must always be maintained and maintained so that the language and culture used are still able and can continue to maintain the character or identity of the nation. Because the nation's identity is colored by culture that can be seen from the form of patterns of life in a society. Life patterns according to Imran Manan [6] include regular repetitive activities, objects, and social life that characterize certain groups.

\section{Discussions}

\subsection{Seven Pillars of Cianjur Community Culture}

Currently the Cianjur Regional Government promotes culture in the Cianjur community through the seven pillars of Cianjur culture. Understanding how the Cianjur community can be studied from the seven things that are used as pillars of its culture. All are closely related to the language he uses himself, namely Sundanese. Language as a symbol as well as a cultural product is a marker of existing characters.

In a Cianjur Info site, it is mentioned that Ngaos is 'chanting', 'reading'. Interpreted as reading all the signs that are in the verses "kauniah" God's verses in the universe. This philosophy can be interpreted that the Cianjur community is expected to have extensive knowledge. Mamaos, Mamaos Art, 'a medium of contemplation to refine the heart which is the application of the human concept of moral mercy. Maenpo, Silat Cianjur. Interpreted as 'every step we carry out must be based on calculations and careful consideration so that it is easy to get the goals we want'. Tatanen (farming), 'covers all activities involving plant cultivation for the benefit of humans, so farming is the application of the concept of prosperity to life. Tangginas (early risers), 'waking up in the morning is marked by the midday prayer in congregation in the mosque so that it makes humans disciplined and facilitated fortune. Someah (polite), 'refined and well-mannered, his behavior is a reflection of Cianjur people. Sauyunan (mutual cooperation), 'helping each other together so that harmony, peace and harmony together'.

The seven pillars of culture above provide a guide for the Cianjur community to become an advanced society. With its first pillar, namely 'Ngaos', it is hoped that the Cianjur community will always try to foster a willingness to read what is there. Not only read micro (what is written) but also read in a macro (reading everything that happens in the universe) so that it makes itself a thinking human being. Other cultural pillars foster Cianjur community to always have the subtlety of mind, readiness in facing life, diligently working, agile, friendly to others, and always living side by side with others (mutual cooperation). Local wisdom is what needs to be maintained and maintained in the face of changing and developing times.

\subsection{The Role of Sundanese Language and Culture in Sundanese People's Life}

Sundanese is a language used as a communication tool by the Sundanese people. If we speak Sundanese, then we are inseparable from the language and culture itself. In its function, Sundanese as well as a tool for developing and supporting Sundanese culture itself. Sundanese language is a part of Sundanese culture. Sundanese society itself is a society that is bound by the awareness and unity of Sundanese culture, and has its own language, namely Sundanese. Language is said to be part of culture, because culture includes many things, behavior, goods or objects, including the values and norms of life that exist. Sundanese culture itself is a culture that grows and lives in Sundanese society.

In relation to the term "Sundanese", Warnaen in Edi S Ekadjati [7] explains that what is meant by the Sundanese is a person who claims to be himself and is recognized by others as Sundanese. According to Edi S Ekadjati [7] there are two criteria in defining Sundanese, namely based on heredity (blood relations), and based on socio-cultural criteria as well. Sundanese based on descent means those whose parents, both from the father or the mother, or both are Sundanese, wherever he was raised and wherever he is. Meanwhile, Sundanese people based on socio-cultural criteria are those who are raised in the Sundanese sociocultural environment, live up to, and use Sundanese cultural values or norms.

Based on these two criteria, according to Edi S Ekadjati [7] it is possible that people born from Sundanese descent, become non-Sundanese because they do not live and use Sundanese social cultural values in their lives. Conversely, those whose parents or ancestors were not Sundanese could become Sundanese because they were born, and raised in the Sundanese socio-cultural environment while understanding and using Sundanese cultural norms and values in their lives. This is what must be understood.

Therefore, in an effort to preserve Sundanese language and culture, we need to understand, appreciate, and use how Sundanese language and culture are in accordance with Sundanese socio-cultural values and norms. Regarding Sundanese as a regional language, from the results of the 1975 National Language Politics Seminar [8] it is stated that there are three functions of regional languages, namely as a "symbol of regional pride, a symbol of regional identity, and a means of communication within the family and regional community". Another function was added in the National Language Policy, which mentioned the function of regional languages as a means of supporting regional culture and Indonesian language and regional languages as supporters of regional literature and Indonesian literature.

In relation to Indonesian, regional languages function as (a) supporting national languages, (b) the language of instruction in primary schools and in certain regions at the beginning level to facilitate the teaching of Indonesian and 
other subjects, and (c) as a development tool as well as supporters of regional culture.

The importance of regional languages, and Sundanese, one of which has been formulated in the explanation of Article 36 of the 1945 Constitution which says that local languages that are well maintained by their speakers will be respected and maintained by the state because the regional languages are part of Indonesian culture that is life. Hiroko Otsuka [9] states that "language is an important element in culture and is a reflection of culture, therefore learning language can deepen culture itself'.

\subsection{Language and Culture as National Character or Identity}

Edi Sedyawati [10] said that national identity is determined by cultural identity and supported by historical awareness. Cultural identity is characterized by cultural values and patterns of various cultural expressions that are specific to the nation concerned. One expression of that culture is language. Language reflects culture. Culture reflects character. Character shows identity. It is true what was said by Ki Hajar Dewantoro in Mochamad Tauchid [11] who said that language and nation are one.

Language is a symbol system used to communicate. Serves to express all thoughts, ideas, ideas, opinions, or feelings to others. The sign system or symbols used in the language have the same values and references among the users [12]. In its arbitrary and conventional nature, the language spoken by speakers reflects the individual or community of the user. This is as stated by A Chaedar Alwasilah [13], that language is a system that we inherit or obtain from the culture or society in which we grow. With the language acquired and inherited, the language becomes strong institutionalized, so individuals cannot change it.

In connection with this, Jason Cenoz and Durk Gorter [14] explain a theory of language relativity (linguistic relativity) which mentions the relationship between language as a symbol with mental functions and the cognitive structure of the wearer. According to him, there are two different opinions regarding the theory are (a) that mental operations are carried out free from the influence of language; language is just a system for expressing ideas, (b) that mental functions are entirely determined by language; language as forming ideas.

Based on the above, each group of language-using communities has special characteristics. These communities have the same ties in their own history and agree on their cultural value system [13]. In its use, people use language in a variety of ways. Variations, variations, or dialects have certain functions in society. For educational activities, doing business, creating literary works, and others.

\subsection{Efforts to Preserve Sundanese Language and Culture}

In Government Regulation Number 25 of 2000 concerning maintenance authority it is stated that the fostering and development of the regional language and culture becomes the authority of the Region. While the authority of the Center is in the development and development of Indonesian language and literature [8].

According to Mahsun [8] explained that in order to improve the quality of the use of regional languages a policy has been formulated to develop regional language teaching through programs: a) Research into the problem of teaching local languages and their solutions; b) Formulation of the curriculum; c) Preparation of special regional language teaching programs that can directly produce regional linguists; d) Determination of the most suitable methodical methodology of language; and e) Library development.

The Indonesian nation is a pluralistic nation with diverse tribes and languages. This is a nation's wealth that needs to be maintained and maintained. Along with the times and the swift flow of globalization, there are various concerns about the erosion of language with the various regional cultures. Local culture that is more in line with the character of the nation seems more difficult to digest, compared with global culture that looks so fast and easy to penetrate into it. In fact, it is often seen among teenagers that they prefer culture from outside rather than their own culture. Therefore, so that the existing regional languages and cultures are maintained, not displaced and not eroded by the global culture, efforts are needed to maintain them. That business is what is called a local cultural preservation effort.

Sundanese language and culture are local cultures that need to be maintained. Local culture is the existing local wisdom. According to Elis Suryani [15] local wisdom includes (a) the concept of local policy, (b) the concept of local intelligence, and the concept of local communities. In anthropology, this local wisdom is known as the local genius, which is also known as local knowledge (indigenous or local knowledge), or local intelligence (local genius), which forms the basis of cultural identity (cultural identity). According to him, local wisdom is a way of life that underlies the various patterns of behavior and actions of each community.

In connection with this effort to maintain Sundanese language and culture, in line with the thoughts of Elis Suryani [15] the defense of Sundanese language and culture aims to: (a) maintain local wisdom by rediscovering and living the values contained in it: (b) fostering a sense of love and positive attitude towards one's own language and culture so as to be able to balance the magnitude of the influence of foreign cultures; and (c) preserving local wisdom by storing and passing down the results of past culture from one generation to the next..

Many efforts can be carried out by us in maintaining or preserving Sundanese language and culture in order to remain victorious, including: a) Making local languages as the development of local content material taught in schools (including universities). Local content can be grouped into two broad groups, namely relating to natural knowledge and those related to cultural knowledge; b) Incorporating local wealth (locality) into literary learning materials in schools; c) Do the translation of local cultural wealth into Indonesian. Besides aiming to enrich Indonesian culture, it also has the 
aim to increase appreciation of local culture; d) Writing formal and informal reading materials and learning materials from kindergarten to university with local cultural sources; e) The technology of the richness of the language, literature and culture of the archipelago so that the younger generation is easy to access, understand, and re-enjoy the richness of the archipelago's culture, including Sundanese culture; f) Activating electronic media (TV) to broadcast various activities that promote local wisdom; g) Upholding Sundanese culture such as maintaining good manners, for example, shaking hands with parents when leaving; Speak politely to people whose age is above us; h) Be polite in relationships; bowing when passing people, saying 'punten' (sorry); i) Preserve, study, and explore local wisdom. Culture will continue to live as long as someone preserves it, continues to study and study it; j) Introducing socio-cultural values to our children and grandchildren; k) Introducing Sundanese culture to strangers or other people; 1) Allocate special hours in the field of education, there are special hours to study Sundanese language and culture; m) Holding delayed competitions; n) Making policies that raise local wisdom, for example making a policy called "Wednesday Nyunda" delay; o) Holding pasanggiri, workshops, and discussions, as well as making Sundanese reading material.

\section{Conclusion}

Language and culture are very related. The two cannot be separated. Through language we can get to know a person's culture or the culture of a nation. From the language used in all its forms, it can be recognized the socio-cultural values contained therein. Because language and culture are in the community, recognizing them is through those languages and cultures. Sundanese language and culture live in the midst of the diversity of the Indonesian people. Therefore, it is one of the nation's wealth that needs to be maintained and maintained. With the magnitude of the influence of globalization that permeates various aspects of life, it is necessary to maintain the efforts of all parties in preserving and regrowing existing local wisdom. Who should maintain it? Of course all of us. Yes, all parties involved to preserve it, both as individuals, community groups, and as policy makers (government). By understanding, and realizing the importance of maintaining this local language and culture, it is hoped that all of us will have a positive attitude and respect for various efforts to preserve local wisdom.

\section{References}

[1] Adhani, Agnes. (2016). Peribahasa, Maknanya, Dan Sumbangannya Terhadap Pendidikan Karakter. Magistra. 97 (XXVIII), 97-110.

[2] Wiguno, Panji Setyo. (2017). Efek Persuasi Peribahasa Serta Implementasi Pembelajarannya di SMA. Transformatika. 1 (1), 90-105

[3] Verhaar. 2016. Asas-Asas Linguistik Umum. Yogyakarta: Gadjah Mada University Press.

[4] Gorter, D. (2013). Linguistic Landscapes in a Multilingual World. Annual Review of Applied Linguistics, 33, 190-212. doi: $10.1017 / \mathrm{S} 0267190513000020$.

[5] Tarigan, Henry Guntur. 1984. Psikolinguistik. Bandung: Angkasa.

[6] Manan, Imran. 1989. Dasar-dasar Sosial Budaya Pendidikan. Jakarta: Depdikbud Dirjendikti.

[7] Ekadjati, Edi S. 1995. Kebudayaan Sunda (Suatu Pendekatan Sejarah). Jakarta: Pustaka Jaya.

[8] Kemendikbud. 2011. Politik Bahasa Risalah Seminar Politik Bahasa. Jakarta: Badan Pengembangan dan Pembinaan Bahasa.

[9] Hiroko, Otsuka. 2010. Makalah Mengenal Jati Diri Budaya Bangsa melalui Bahasa. Budaya Nusantara sebagai Basis Pendidikan. Editor Siti Maryam. Bandung: CELTICS Press.

[10] Sedyawati, Edi. 2007. Keindonesiaan dalam Budaya. Jakarta: Wedatama Widya Sastra.

[11] Tauchid, Moch, dkk. 1967. Karya Ki Hadjar Dewantara. Bagian 11 A Kebudayaan. Jogjakarta: Madjelis-Luhur Persatuan Taman Siswa.

[12] Gorter, D. (2008). Introduction: The Study of the Linguistic Landscape as a new Approach to Multilingualism. International Journal of Multilingualism. 3 (1) 1-7. doi: $10.1080 / 14790710608668382$.

[13] Alwasilah, A. Chaedar. 1993. Pengantar Sosiologi Bahasa. Bandung: Angkasa.

[14] Jason Cenoz., \& Gorter, D. (2009). Linguistic landscape: Expanding the scenery. New York: Routledge.

[15] Suryani, Elis. (2010). Ragam Pesona Budaya Sunda. Bandung: Ghalia Indonesia. 